\title{
ALTERATION OF RIGHTS IN CALIFORNIA PUBLIC SECURITIES
}

Public entities may finance needed governmental services and facilities in a number of ways, mcluding spending from current revenue, ${ }^{1}$ leasing with option to purchase, ${ }^{2}$ and issuing securities. ${ }^{3}$ The latter, generally termed financing through the inunicipal bond market, is probably the most common method, and is used by a variety of public entities in California under a variety of authorizing statutes and constitutional provisions. ${ }^{4}$ This Comment is concerned with the relative rights of the three most inportant participating parties to a municipal bond transaction: voters, bondholders, and landowners; and with the effect subsequent legislative changes may have on these rights. Legislative change, as used in this Comment, includes both state statutory changes and changes by the issuing entity.

The rights of each of the three groups differ, as do the foundations of these rights. Voters have rights in bond issues that require voter approval. Bondholders' rights depend on the terms of the bond they own. ${ }^{5}$ Landowner's rights may be conveniently classified in three groups: (1) Landowners as taxpayers have the rights of voters in bonds that are issued with voter approval; ${ }^{\circ}$ (2) Landowners as debtors have rights in bonds that are issued without voter approval to cover the cost of improvements that benefit specific property and that constitute direct liens on the property benefited; ${ }^{7}$ (3) In California landowners as landowners appear to have some special contractual rights to resist change in bonds that are issued without voter approval to represent unpaid improveinent assessinents, ${ }^{8}$ but which do not constitute direct hens on the benefited property.

In its three sections, this Cominent will analyze the rights of each of the three groups: voters; bondholders, and landowners. This Com-

${ }^{1}$ See, e.g., CAL. CoNsT. art. XI, § 18.

2 See, e.g., County of Los Angeles v. Byram, 36 Cal. 2d 694, 227 P.2d 4 (1951); Dean v. Kuchel, 35 Cal. 2d 444, 218 P.2d 521 (1950).

${ }^{3}$ See CaL. Const. art. XVI, § I.

4 E.g., CaL. Const. art. XVI, § I; art. XI, § 18; CaL. Gov'x Code §§ 29900-43.

5 See notes 36,46 infra.

6 Mulcahy v. Baldwin, 216 Cal. 517, 15 P.2d 738 (1932). For examples of bonds requiring voter approval before issue, see, e.g., CAL. CoNst. art. XVI, § 1; art. XI, § 18; CAL. Gov'T CODE §§ 29900-43; CAI. WATER CODE \$§ 52100-302.

7 E.g., Creighton v. Pragg, 21 Cal. 115 (1862). For examples of bonds issued without voter approval and that are direct hens on the property, see, e.g., CAL. STrTs. \& Higrs. CodE $\S \S 4530-54$.

8 See County of San Diego v. Childs, 217 Cal. 109, 17 P.2d 734 (1932). For an example of bonds of this type see, e.g., CaL. STRTs. \& HigHs. CODE $\$ \S 8570-8850$. 
ment deals with the rights landowners have, or appear to have, with regard to bonds, and not their right, as parties obligated to pay taxes or assessments, to insist that the collecting entity observe statutory limitations.

\section{I}

RELATIONSHIP BETWEEN VOTERS AND THE ISSUING ENTITY

The state, counties, cities, towns, boards of education, and school districts are prohibited by the California constitution from incurring general obligation indebtedness that exceeds the current year's revenue, unless a specified majority of the voters approves a greater indebtedness. $^{10}$ Voter approval is also required for the issuance of revenue bonds, ${ }^{11}$ although revenue bond debt is not subject to the debt limitations. Revenue bond debt is not considered public indebtedness, because the bondholder may look for payment only to the revenue produced by a specified enterprise ${ }^{12}$ and not to the issuing entity's taxing power. Some other public entities, such as reclamation districts, are also required to obtain voter approval before issuing specified bonds. ${ }^{13}$ The task of the courts, when confronted with proposed changes in bond issues that have been approved by the voters, is to harmonize the ever-present need for legislative flexibility with the constitutional and statutory policy that the electorate shall directly control public indebtedness and shall also control the issue of certain types of bonds.

\section{A. Elements of Voter Approved Bond Issues}

Two theories have been used to analyze the relationship between voters and a bond issuing entity: grant of authority; and contract. Although the California courts have not always distinguished between these theories, the basic purpose of voter approval-public control of spending - has been recognized. The leading case, Peery v. City of Los Angeles, ${ }^{14}$ holds that the approval of a proposition by the electorate is a grant to the entity of authority to act. The court refused to give effect to a statute passed after the bond election, which purported to authorize sale of the bonds at less than par, because to secure approval of one set of terms and then to issue bonds under another would be a "fraud upon

${ }^{\circ}$ CAL. Const. art. XVI, $\$ 1$; art. XI, $\S 18$. The state may incur indebtedness up to $\$ 300,000$ without seeking the approval of the voters. CaI. Corss. art. XVI, $\$ 1$.

10 See CAL. Const. art. XVI, § 1; art. XI, § 18.

i1 See, e.g., Sanitation, Sewer and Water Revenue Bond Law of 1941, CaL. Gov's Cope $\S \S 54300-71$.

12 See, e.g., CAL. Gov'T Code § 54420.

13 See, e.g., CAL. WATER Code \$§ 52200-85.

14187 Cal. 753, 203 Pac. 992 (1922). 
the electors."15 The result and the reasoning are well tailored to serve the policy of public control of expenditure. The court correctly recognized that the bond issuing entity should not be permitted to induce voter consent with proposed terms, and then to alter the terms to the voter-taxpayer's detriment. This rationale is not designed to prevent all change, nor to foster arbitrary and doctrinaire adherence to bond proposals as such, but rather to allow public approval to have realistic force.

Courts have also characterized the relationship between the voters and the issuing entity as contractual. ${ }^{16}$ In O'Farrell v. County of Sono$m a,{ }^{17}$ for example, the court used a contract theory in the following situation. The voters had approved a bond issue for 4.0 miles of road in Sonoma County. The amount approved was 85,000 dollars. The plaintiff, a property owner, sued to enjoin the expenditure of $72,840.60$ dollars for only 1.93 miles. The court, in overruling a demurrer to the complaint, found that a contract between the county and the individuals whose property was affected ${ }^{18}$ arose through the consent of the electorate. The court said the entire 4.0 miles of road was specified in the contract and the board of supervisors had no power to use virtually all the funds to build only a portion of it. The O'Farrell case would lose none of its force if it were placed on the same basis as Peery: A taxpayer may enjoin an act exceeding the authority granted by the voters. It is preferable, moreover, to use the grant of authority analysis because it more accurately reflects the nature of voter approval, and in addition may assist in overcoming or avoiding some of the questions about impairing the obligation of contract which inhere in any contractual analysis.

The grant of authority analysis is clearly set out in the case of State School Building Finance Comm. v. Betts, ${ }^{19}$ in which the court enunciated

15 Id. at 767,203 Pac. at 998.

16 Many cases mistakenly cite $P_{e e r y}$ as authority for a contractual analysis. See, e.g., County of San Bernardino v. Way, 18 Cal. 2d 647, 117 P.2d 354 (1941); City of Redwood City v. Meyers, 7 Cal. 2d 283, 60 P.2d 291 (1936); Metropolitan Water Dist. v. Toll, 1 Cal. 2d 421, 35 P.2d 519 (1934); Golden Gate Bridge \& Highway Dist. v. Filmer, 217 Cal. 754, 21 P.2d 112 (1933); Los Angeles County Flood Control Dist. v. Wright, 213 Cal. 335, 2 P.2d 168 (1931) ; O'Farrell v. County of Sonoma, 189 Cal. 343, 208 Pac. 117 (1922). The court in Peery refused to call the relationship contractual, although terming it "a status analogous to such relation." Peery, supra at 767, 203 Pac. at 998.

17189 Cal. 343, 208 Pac. 117 (1922).

18 The voter is said to speak for the taxpayer. Mulcahy v. Baldwin, 216 Cal. 517, 15 P.2d 738 (1932). Once rights in voter approved bonds arise, they are enforced by taxpayers. When property taxes go to pay the bonds the "landowner" is the taxpayer who has the rights of the voters. Landowners should have no special status qua landowners to prevent change.

19216 Cal. App. 2d 685, 31 Cal. Rptr. 258 (1963). 
the relationship between the voter and a bond issuing entity. The court advanced the following argument: The voter has no contract with the entity; the reason substantial changes in bond issues cannot be allowed is that the issuing entity is prohibited by the constitution from acting without voter approval; there is no power to act beyond the extent of the approval. Thus analyzed, the courts' major problem is to determine the extent and effect of the grant of authority from the voters.

The terms of the grant of authority include the ballot proposition, ${ }^{20}$ applicable state statutes, ${ }^{21}$ the terms of the act establishing the entity ${ }^{22}$ and the terms of the original order of the legislative body of the entity, even if it is not presented to the voters. ${ }^{23}$

The terms of the proposed bond issue may be formulated as broadly or as narrowly as the pertinent statutes allow. ${ }^{24}$ Once the proposal is approved by the electorate, a public entity may not disregard terms im the proposal, even if voter approval for the particular terms was not originally necessary. ${ }^{25}$ The courts have been reasonable in concluding that the grant of authority includes existing conditions as well as the ballot proposal. Voters presumably evaluate bonds in the light of these conditions; to allow legislative changes to take effect without voter consent could seriously defeat their expectations. ${ }^{28}$

\section{B. Effect of Legislative Change}

Once the scope of the terms of the bond issue lias been determined, the courts must determine the effect of those terms and the type and degree of change that will be permitted. California courts have consistently recognized that the policy of public control of spending precludes

${ }^{20}$ See, e.g., Skinner v. City of Santa Rosa, 107 Cal. 464, 40 Pac. 742 (1895).

21 E.g., Peery v. City of Los Angeles, 187 Cal. 753, 203 Pac. 992 (1922). There is an exception to the rule that existing statutes are incorporated into the grant of authority. This exception concerns statutory or constitutional debt limits that place a maximum on the amount of bonded indebtedness that may be incurred by a bond issuing entity. See Clark v. City of Los Angeles, 160 Cal. 30, 116 Pac. 722 (1911). A bond issue that would exceed the debt limit when voted may be validated by legislation, subsequent to voter approval but before issue, raising the limit. The reason given is that bonds do not represent debts until they are issued, and hence cannot exceed the limit on bonded indebtedness if the himit is raised prior to the issue. The better reason, however, seems to be that the voters were aware of their tax burden and approved the bonds in spite of it. There is no reason to assume that voters, having approved a bond issue, will withdraw their consent when the bonds are made legally issuable. (1931).

22 E.g., Los Angeles County Flood Control Dist. v. Wright, 213 Cal. 335, 2 P.2d 168

23 Jenkins v. Williams, 14 Cal. App. 89, 111 Pac. 116 (1910).

24 See, e.g., O'Farrell v. County of Sonoma, 189 Cal. 34.3, 208 Pac. 117 (1922).

25 See Skinner v. Santa Rosa, 107 Cal. 464, 40 Pac. 742 (1895).

26 See discussion in text accompanying notes $36,37,42$ infra for a discussion of the effect of beneficial changes. 
most changes that would affect these terms and purposes, whether they are changes by the issuing entity in the terms or purposes of the bond, or state statutory changes. ${ }^{27}$ However, some changes are permissible, and, under certain conditions; extremely desirable.

\section{Retroactive Application of Statutory Change}

Courts generally refuse to give retroactive effect to statutes affecting voter approved bond issues. ${ }^{28}$ When such effect is given it is because they find that the terms of the authorization itself include provisions anticipating future changes. These provisions are referred to in this Comment as "provisions anticipating change."

In Los Angeles County Flood Control Dist. v. Wright, ${ }^{29}$ bonds were voted for a specific type of dam in a certain location. A subsequent state statute required approval by a state agency, which refused to approve the dam. This was held sufficient reason to change the type and location of the dam. The Los Angeles County Flood Control Act, ${ }^{30}$ which created the bond issuing entity, contained a provision anticipating changes to meet changed conditions; by approving the issue, which incorporated the terms of the act, the voters had authorized changes in accord with this provision. The result was desirable. To resubmit the proposal to the voters would have entailed considerable delay, expense, and inconvenience.

In State School Building Finance Comm. v. Betts, ${ }^{31}$ the bond proposal provided for repayment "as provided by law." A subsequent ainendment to the bond act changed repayment conditions. The State Treasurer refused to sign the approved bonds to be issued under the new law. The court granted mandamus to compel signing and stated that "as provided by law" contemplated amendments to the law that existed at the time the bonds were approved, and that the voters had given their approval with knowledge of this provision.

These cases demonstrate the desirability of a clause in the bond authorization that contemplates change in the statutes affecting the particular bond issue. Unless some such provision is included, courts must deny effect to statutory changes that adversely affect voters' rights, or that substantially depart from the approved purpose. To do other-

27 E.g., Peery v. City of Los Angeles, 187 Cal. 753, 203 Pac. 992 (1922). See also Merchant's Nat'1 Bank of San Diego v. Escondido Irrigation Dist., 144 Cal. 329, 77 Pac. 937 (1904).

28 See note 27 supra.

29213 Cal. 335, 2 P.2d 168 (1931).

80 CaL. UNCODIFIED WATER LAWS, §§ 28(1)-(23) (West 1956).

81216 Cal. App. 2d 685, 31 Cal. Rptr. 258 (1963). 
wise would deprive the public of its control of spending. ${ }^{32}$ Such a clause provides flexibility within the authority given by the public.

\section{Effect of Change by the Issuing Entity}

Action by the legislative body of the bond issuing entity that adversely affects riglits of parties to a prior bond issue, like similar action at the state level, is usually denied effect. ${ }^{33}$ The types of action may conveniently be classified as follows: (1) action that increases the taxpayer's financial burden; (2) action that decreases the taxpayer's financial burden; (3) action that commits the funds raised to some purpose other than that for which the bond issue was approved.

When the legislative body of the issuing entity lias sought to increase the taxpayer's burden without his consent, courts lave uniformly leld for the taxpayer, ${ }^{34}$ because they will not infer authorization of terms more onerous than those contained in the approved proposal. ${ }^{35}$

When cliange would benefit the taxpayer, courts generally permit action by the issuing entity. ${ }^{36}$ In Town of Martinez $v$. Johnson, ${ }^{37}$ bonds were voted at six per cent interest. When the city council attempted to issue the bonds at five per cent, the town clerk refused to sign them. The court, granting mandanus, said that the legislature did not intend to hold municipal corporations to the amount stated in the ordinance if more beneficial terms were available. Courts properly distinguisl between situations where the taxpayer is benefited and those where his burden is increased..$^{38}$ Authority to issue bonds on more favorable terms may be safely assumed, and courts can ascertain with a reasonable degree of certainty whether or not a change is financially beneficial to the voter-taxpayer.

However, control of spending relates not only to the amount of money spent, but also to the purposes for which it is authorized. Tle

32 Voter approval of an issue that contains a provision anticipating change in effect constitutes a delegation by one segment of the public-that which approves the issue-to another -that which, through its elected representatives, changes the terms-of the control over indebtedness which the constitution dernands.

33 O'Farrell v. County of Sonoma, 189 Cal. 343, 208 Pac. 117 (1922); Peery v. City of Los Angeles, 187 Cal. 753, 203 Pac. 992 (1922); Skinner v. City of Santa Rosa, $107 \mathrm{Cal} .464$, 40 Pac. 742 (1895); Jenkins v. Williams, 14 Cal. App. 89, 111 Pac. 116 (1910). See City of Redwood City v. Meyers, 7 Cal. 2d 283, 60 P.2d 291 (1936) (dictum).

34 See, e.g., cases cited note 30 supra.

35 Skinner v. City of Santa Rosa, 107 Cal. 464, 40 Pac. 742 (1895).

36 County of San Bernardino v. Way, 18 Cal. 2d 647, 117 P.2d 354 (1941); Town of Martinez v. Johnson, 201 Cal. 397, 257 Pac. 853 (1927). See also City of San Diego v. Millan, 127 Cal. App. 521, 16 P.2d 357 (1932) (dictum); Cole v. City of Los Angeles, 180 Cal. 617, 182 Pac. 436 (1919) (dictum).

37201 Cal. 397, 257 Pac. 853 (1927).

38 See id. at 400,257 Pac. at 855. 
purposes for which bonds are voted form an integral part of the grant of authority to the entity. ${ }^{39}$ Courts do not ordinarily permit departure from approved purposes. ${ }^{40}$ Courts have, however, allowed bond issuing entities to anticipate changes to meet certain conditions. In Los Angeles Flood Control Dist. v. Wright ${ }^{41}$ a provision anticipating changed conditions was contained in the statute creating the issuing entity. The court therefore approved a change in the type of dam that was origimally approved. The reasons for allowing provisions for change by the issuing entity are the same as the reasons for allowing anticipation of state statutory changes. Such provisions should, however, be spelled out in the proposal submitted to the voters.

Changes in purpose which benefit the taxpayer present more difficult questions than changes in financial terms which benefit the taxpayer. Courts can easily decide that issue of bonds at five per cent rather than six per cent benefits a taxpayer who must pay the interest, and consent is easily inferred. ${ }^{42}$ There is no way, short of a new election, that a court could be sure voters would approve a change in purpose. Although some courts have stated that changes of purpose beneficial to the taxpayer would be allowed, even absent any provision anticipating change, ${ }^{43}$ no court has so held. In City of San Diego v. Millan ${ }^{44}$ bonds to raise funds for construction of a dam were approved by the voters. The city council passed a resolution authorizing surplus funds from the sale of these bonds to be used to purchase other bonds issued by the city. The court approved this use of the funds and supported its decision in part by a statement that beneficial changes in purpose were permissible. However, the court also found statutory authorization for purchase of bonds with the funds. Similarly, in El Dorado Irrigation Dist. v. Browne, ${ }^{45}$ the court said that substantial changes in purpose that benefit the taxpayer are permissible prior to the issue of bonds. The holding of the case,

39 E.g., O'Farrell v. County of Sonoma, 189 Cal. 343, 208 Pac. 117 (1922).

40 City of Redwood City v. Meyers, 7 Cal. 2d 283, 60 P.2d 291 (1936) (dictum); O'Farrell v. County of Sonoma, $189 \mathrm{Cal}$. 343, $208 \mathrm{Pac} .117$ (1922); Carter v. Tilghman, $119 \mathrm{Cal}$. 104, 51 Pac. 34 (1897) (special tax approved by voters) ; Hunter v. County of Santa Barbara, 110 Cal. App. 698, 294 Pac. 1082 (1930); Calif. Highway Comm'n v. Ballard, 77 Cal. App. 404, 247 Pac. 527 (1926). In Hughson v. Crane, 115 Cal. 404, 47 Pac. 120 (1896), the board of directors of an irrigation district used bond funds for purposes that had not been approved and the court refused to sell land to pay the interest on bonds on the ground that the bonds did not constitute a valid indebtedness and could not be enforced.

41213 Cal. 335, 2 P.2d 168 (1931). See text accompanying notes 29, 30 supra.

42 See Town of Martinez v. Johnson, 201 Cal. 397, 257 Pac. 853 (1927); text accompanying notes 37,38 supra.

43 El Dorado Irrigation Dist. v. Browne, 216 Cal. 269, 13 P.2d 921 (1932) (dictum);

City of San Diego v. Millan, 127 Cal. App. 521, 16 P.2d 357 (1932) (dictum).

44127 Cal. App. 521, 16 P.2d 357 (1932).

45216 Cal. 269, 13 P.2d 921 (1932). 
however, is that the proposal submitted to the voters was broad enough to include the changes in purpose. ${ }^{48}$ The constitutional and statutory policy of public control of spending dictates that the distinction between beneficial changes in financial terms and changes in purpose that may appear beneficial be maintained; and that changes in purpose be deemed beneficial only when it is clear that voter consent may safely be inferred.

\section{II}

\section{RELATIONSHIP BETWEEN BONDHOLDER AND ISSUING ENTITY}

\section{A. Nature of the Relationship}

Many public bond issues require approval by the electorate. ${ }^{47}$ There are bonds, however, that may be issued without such approval..$^{48}$ The relationship between the bondholder and issuing entity is deemed contractual as to both types ${ }^{49}$ but the source of the contract terms is different. ${ }^{50}$ When bonds are approved by the voters, the terms of that approval limit the extent to which the issuing entity may bind the taxpayers. ${ }^{.1}$ When bonds need not be approved by the voters, the limitations are in the governing statutes.

The terms of the contract include the terms stated on the face of the bond, ${ }^{52}$ and the existing relevant statutes. ${ }^{53}$ When voter approval is not required, statutes at the time of issue apply. ${ }^{54}$ However, when voter approval is required, it is not clear whether the statutes incorporated are those in effect at the time the bond issue is authorized or those in effect when the bonds are issued. ${ }^{55}$ In Copeland v. Raub, ${ }^{56}$ the bonds were approved in November 1919 and sold in March of 1930. The law in 1919 re-

46 Cases in which the court found changes to be within the scope of the proposal approved at the polls include: Nevada Bank v. Steinmitz, 64 Cal. 301,30 Pac. 970 (1882); State School Bldg. Fin. Coinm. v. Betts, 216 Cal. App. 2d 685, 31 Cal. Rptr. 258 (1963); County of San Diego v. Perrigo, 155 Cal. App. 2d 644, 318 P.2d 542 (1957); SacramentoYolo Port Dist. v. Rodda, 90 Cal. App. 2d 837, 204 P.2d 372 (1949); County of Alameda v. Garrison, 108 Cal. App. 122, 291 Pac. 464 (1930).

47 See notes 10-45 supra and accompanying text.

48 E.g., CaI. StrTs. \& Higrs. CODE $§ \S 4500-54,8500-8351$.

49 E.g., Islais Co. v. Matheson, 3 Cal. 2d 657, 45 P.2d 326 (1935) (voter approved); County of Los Angeles v. Rockhold, 3 Cal. 2d 192, 44 P.2d 340 (1935) (not voter approved). 50 The terms of a voter approved bond issue are of extreme importance to the bondholder. See discussion of Hughson v. Crane, 115 Cal. 404, 47 Pac. 120 (1896), at note 40 supra.

51 Jenkins v. Williams, 14 Cal. App. 89, 111 Pac. 116 (1910).

52 Irvine v. Reclamation Dist. No. 108, 24 Cal. 2d 468, 150 P.2d 428 (1944).

${ }^{53}$ E.g., Islais Co. v. Matheson, 3 Cal. 2d 657, 45 P.2d 326 (1935).

54 Chapman v. Jocelyn, 182 Cal. 294, 187 Pac. 962 (1920).

55 See Copeland v. Raub, 36 Cal. App. 2d 441, 97 P.2d 859 (1940).

5636 Cal. App. 2d 441, 97 P.2d 859 (1940). 
quired payment of the assessments in cash. In 1923 an amendment provided that taxpayers who owned bonds for which they were assessed could use the bonds and matured interest coupons to pay the assessment. The court gave effect to the amendment and refused to compel payment of the assessment in cash. The court did not discuss any possible application of the 1919 statute.

If an amendment adversely affects the taxpayer, and the bond issue terms that were approved at the polls contained no provision anticipating change, it is clear that the taxpayer may prevent the amendment from taking effect. ${ }^{57}$ However, if the approval of the voters is viewed as a grant of authority to issue bonds on the approved terms, or on terms more favorable to the taxpayer; a statutory change before the bonds are issued that is beneficial to the taxpayer should become part of the entity's contract with the bondholder. Bondholders should not be able to regard the approved proposal as an immutable contract between the voters and the issuing entity, but rather as a grant of authority, subject to expansion within the terms of the grant. Bondholders do not buy bonds until the bonds are issued, and it is the situation as of issuance which forms the basis of their rehance. ${ }^{58}$

\section{B. Legislative Changes Affecting Bondholders}

Since bonds are contracts, the provisions in the United States and California Constitutions that prohibit the impairment of obligation of contracts apply. The prohibition extends to all types of legislative impairment, whether by a change in the bonds by the issuing entity, ${ }^{59}$ or a statutory change or addition at the state level..$^{60}$

Determination that changes constitute impairment is generally a case by case matter. ${ }^{61}$ If change substantially impairs the rights of bondholders, it must be denied effect. Changes in form, which have hittle or no effect on the bondholders' rights, should not be prohibited. To do so

57 See cases cited note 33 supra.

58 Both the taxpayer and bondholder are adequately protected without relying on a contract between the voter and issuing entity. The taxpayer is protected through his right to prevent action outside the grant of authority; the bondholder may measure his rights by statutes existing at the time he buys his bonds.

59 See, e.g., Los Angeles County Flood Control Dist. v. Wright, 213 Cal. 335, 2 P.2d 168 (1931).

60 E.g., County of Los Angeles v. Rockhold, 3 Cal. 2d 192, 44 P.2d 340 (1935).

61 Von Hoffman v. City of Quincy, 71 U.S. (4 Wall.) 535 (1866). See also Hochman, The Supreme Court and the Constitutionality of Retroactive Legislation, 73 HARv. L. Rev. 692 (1960). For a general discussion of retroactive law making, see Slawson, Constitutional and Legislative Considerations in Retroactive Law Making, 48 CALIF. L. REv. 216 (1960). 
would hinder administration of bond issues. California courts have allowed legislative change in a few cases, but only where the change was deemed to have no detrimental effect on the rights and remedies of the bondholder, or where bondholders agreed to the change.

\section{Changes by the Issuing Entity}

Courts generally prohibit clianges in bonds by the issuing entity, on the ground that to do so would impair the obligation of the bondholder's contract. In Selby v. Oakdale Irrigation Dist. ${ }^{62}$ the court, recognizing the necessity for protecting the remedies of bondholders, held void a resolution by the board of directors of the irrigation district limiting the bondholders' right to payment, since the resolution impaired the effectiveness of the reniedies for which the bondholders contracted. However, in at least one case, changes affecting bondholders rights have been allowed. In County of San Bernardino v. Way, ${ }^{03}$ the court allowed cancellation of delinquent taxes pledged to the payment of bonds, after finding the taxes uncollectible due to declining property values. The court recognized the bondholders' rights to their security, but found that the worthless rights, if insisted upon, would make it likely that the debt would never be paid. The court based its decision on its determination of the realities of the situation, and on that basis seenis correct. ${ }^{64}$ However, the case is probably authority only for its particular fact situation. Indiscriminate cancellation of delinquent taxes pledged to the payment of bonds could result in denial of the rights of bondholders, and could also have a seriously detriniental effect on the marketability of public securities.

\section{Statutory Changes}

Only prospective application of new and amended state statutes that substantially affect bondholders' rights has been allowed, on the ground that to give them retroactive effect would impair the obligation of the bondholders' contract. ${ }^{65}$ The pohicy reasons for not allowing the statutes to have retroactive effect are the sane as those for not allowing issuing

62140 Cal. App. 171, 35 P.2d 125 (1934).

e3 18 Cal. 2d 647, 117 P.2d 354 (1941).

61 By cancelling the taxes, property in the district was put back on the assessment roll. The delinquent assessments on the property in the district exceeded the value of the property. But cf. May v. Board of Directors of El Camino Irrigation Dist., 34 Cal. 2d 125, 208 P.2d 661 (1949), where the issuing entity was compelled to levy an assessment even though there was hitle chance of payment.

65 E.g., Shouse v. Quinley, 3 Cal. 2d 357, 45 P.2d 701 (1935); County of Los Angeles v. Rockhold, 3 Cal. 2d 192, 44 P.2d 340 (1935). 
entities to change the rights and remedies of bondholders. It makes no difference whether ${ }^{66}$ or not ${ }^{67}$ the bonds have been submitted to the voters - statutes altering the remedy to the detriment of the bondholder are impermissible. Also invalidated have been statutes altering the method of payment. ${ }^{68} \mathrm{On}$ at least one occasion, a statute allowing a certain percentage of the bondholders to consent to changes in the bonds ${ }^{69}$ was invalidated as to nonconsenting bondholders.

Cases that do allow retroactive apphication of new or amended statutes do so when such apphication will not impair the contract. Moody v. Provident Irrigation Dist. ${ }^{70}$ gave retroactive effect to a statute that prohibited money judgments against the district. The statute allowed bondholders to register bonds for payment; entitling the bondholder to increased interest and tolling the statute of himitations until money was available for payment. A bondholder sued for a money judgment, claiming that such judgments constituted part of his contract with the entity. The court said since another remedy of equal effectiveness was provided, demal of money judgments did not impair the obligation of contract. In this case the only effect of a money judgment would have been to protect the debt from being barred by the statute of limitations. Application of the new enactment was desirable, since prohibition of money judgments would serve to expedite the settlement of claims, saving time and money that would otherwise be spent on litigation rendered needless once the statute of limitations was tolled. Imphicit in this decision is a recognition that legislative flexibility is needed, and that the essence of the right, rather than the form, deserves protection.

Statutes of himitation affecting rights of bondholders liave been given retroactive effect, on the theory that by merely limiting the time in which an action may be brouglit they do not affect the bondholder's rights and remedies. ${ }^{71}$ The limitation must specify a reasonable time in which the

${ }^{66}$ Islais Co. v. Matheson, 3 Cal. 2d 657, 45 P.2d 326 (1935). In this case the landowner applied for a writ of mandate to compel the acceptance of payments pursuant to amendments passed after the bonds were sold. The court refused to grant the writ on the ground that lesser payments would impair the rights of the bondholder.

67 Houston v. McKenna, 22 Cal. 550 (1863); Creighton v. Pragg, 21 Cal. 115 (1862).

68 E.g., Shouse v. Quinley, 3 Cal. 2d 357, 45 P.2d 701 (1935).

69 E.g., County of Los Angeles v. Rockhold, 3 Cal. 2d 192, 44 P.2d 340 (1935) (75\% of bondholders could consent to change and bind all bondholders).

7012 Cal. 2d 389, 85 P.2d 128 (1938).

71 E.g., Scheas v. Robertson, 38 Cal. 2d 119, 238 P.2d 982 (1951); Rand v. Bossen, 27 Cal. 2d 61, 162 P.2d 457 (1945). See also United States v. Morena, 245 U.S. 392 (1917); Saranac Land \& Timber Co. v. Comptroller of New York, 177 U.S. 318 (1899); Terry v. Anderson, 95 U.S. 628 (1877). One reason that has been given is that parties contract in the light of the legislature's power to impose statutes of limitation retroactively. National Surety Co. v. Architectural Decorating Co., 226 U.S. 276 (1912). 
action may be brought, ${ }^{72}$ but in this regard courts give great deference to decisions of the legislature. ${ }^{73}$

\section{Contractual Provisions Anticipating Change}

Many of the problems that arise when a bond issue is sought to be changed vis-à-vis the bondholders may be solved by acquiring consent to the change. It is well settled that consent to a change in the terms of a bond issue, so far as the consenting bondholder is concerned, will validate legislative action to the extent of that consent. ${ }^{74}$

The most common problems in this area involve refunding plans. ${ }^{75}$ Consent is usually not difficult to obtain, since refunding is almost always intended to improve the bondholder's position. However, a minority may refuse to approve proposed changes, and then the problem of protecting its rights under the original contract arises. In County of Los Angeles $v$. Rockhold, ${ }^{76}$ the court invalidated an entire refunding scheme because there was no provision to protect the few dissenting bondholders.

Without rigorous protection of minority rights, the security of the terms of public bond issues would be difficult to assure. A judicially sanctioned method of providing for change is to include a clause in the bonds empowering a specified majority of bondholders to consent to alteration of the terms of an issue for all bondholders. Livingston $v$. Robinson ${ }^{77}$ provides an example of this approach. The terms of refunding bonds accepted by bondholders contained a provision that consent of seventy-five per cent of the holders of the refunding bonds would be sufficient to change the interest rate with respect to all holders of the refunding bonds. The court enforced this provision over the protest of one bondholder.

\section{IIII}

\section{RIGHTS OF LANDOWNERS AFFECTED BY A BOND ISSUE}

The most confused legal relationship in Cahfornia bond law is that between landowners affected by a bond issue and the legislative branches of bond issuing entities. The courts have variously described the status

72 Rombotis v. Fink, 89 Cal. App. 2d 378, 201 P.2d 588 (1949).

73 Ibid.

74 See, e.g., County of San Diego v. Hammond, 6 Cal. 2d 709, 59 P.2d 478 (1936).

75 Refunding, as used in bond law, means to issue new bonds, usually on lower terms, to lessen the burden on taxpayers, and reduce defaults. The bonds are exchanged for the old outstanding bonds.

763 Cal. 2d 192, 44 P.2d 340 (1935).

7710 Cal. 2d 730, 76 P.2d 1192 (1938). 
of the landowner as follows: a party to a contract with the issuing entity; ${ }^{78}$ a party to a contract with the bondholder; ${ }^{79}$ a mere taxpayer ${ }^{80}$

The easiest way to understand landowners' rights in bonds is to examine the sources of these rights. The sources may be placed in three convenient categories. In the first category, bonds; hereinafter referred to as "direct lien bonds," are issued to cover the cost of an improvement, and the bondholder is given a direct lien on a specific piece of the landowner's benefited property. ${ }^{81}$ In the second; the landowner, as a taxpayer, represents the voter and enforces the terms of a voter approved bond issue. ${ }^{82}$ The third category includes bonds, termed "general assessment bonds," in this Comment, which are issued by a public entity and secured by a fund maintained by the entity into which are paid the assessments for the benefited property. The bond fund, and not the property assessed, constitutes the bondholder's security ${ }^{83}$

\section{A. Direct Lien Bonds}

When bonds are a direct lien on benefited property courts have held that a contract exists between the landowner and the bondholder. ${ }^{84}$

The contractual analysis is warranted in this situation. The landowner's choice is governed by the legal consequences that exist at the time he makes it. In essence the landowner, by not paying the assessment; has chosen to pay a certaim amount with interest, and has given a hen on

78 O'Farrell v. County of Sonoma, 189 Cal. 343, 348, 208 Pac. 117, 119 (1922); Merchant's Nat'l Bank of San Diego v. Escondido Irrigation Dist., 144 Cal. 329, 335, 77 Pac. 937, 939 (1904). Although the courts in these cases say the contract is between the landowner and the state, it is clear that the relationship is between the landowner and the issuing entity.

79 E.g., Sutter Basin Corp. v. Brown, 40 Cal. 2d 235, 241, 253 P.2d 649, 652, cert. denied, 346 U.S. 855 (1953). In a concurring opinion, Justice Traynor urges prospective overruling of the contractual analysis as respects the relationship between landowner and bondholder.

80 County of San Diego v. Hainmond, 6 Cal. 2d 709, 59 P.2d 478 (1936). The court in this case also recognized a contract between the bondholder and landowner.

81 E.g., CaI. StrTs. \& Hrgers. Code $\S 4573$.

82 See, e.g., O'Farrell v. County of Sonoma, 189 Cal. 343, 208 Pac. 117 (1922).

83 E.g., CaI. StrTs. \& HigHS. Code \$\$ 8500-8851.

84 E.g., Creighton v. Pragg, 21 Cal. 115 (1862). The relationship may be illustrated by the procedure under the Street Opening Act of 1903, CaI. STRTs. \& HraHs. Code $\$ \S 4400-43$, and the Street Opening Bond Act of 1911, CaI. Stris. \& HrGess. Code $\$ \$ 4500-677$. A public entity determines that inprovements are necessary, and hires a contractor to perform the work. $\S 4530$. When the work is completed, the cost is apportioned and assessed to the property owners who are benefited. $\$ \S 4270-91$. The landowner may then pay the assessment. $\S 4323$. If the assessment is not paid, bonds are issued to represent the indebtedness of the defaulting landowner. $\S 4554$. The bonds are direct liens on the property of landowners who have chosen not to pay. $\S 4573$. The bonds and a specified rate of interest are then paid over a period of time. $\$ 4551$. For a discussion of similar bond procedures, see Rogers, 1911 Act Bonds, 36 Calrf. State Bar J. 323 (1961); Comment, 53 CaIr. L. Rev. 364 (1965). 
his land as security. The bondholder has agreed to look to a single lot for payment of the bond. The relationship is between private parties, with the issuing entity as a middleman, and the relationship should be treated as a contract in order to protect the landowner from detrimental changes in the terms of his obligation.

\section{B. Landowner Rights in Voter Approved Bonds}

When courts deal with the rights of landowners in conjunction with a voter approved bond issue, they should make it clear that the term landowner is used synonymously with taxpayer, and that as taxpayers the landowners liave only the rights of voters in voter approved bonds. In O'Farrell v. County of Sonoma, ${ }^{85}$ the court stated that a landowner had a "contract" with the issuing entity. In that case, however, the landowner had no special rights as a landowner. It was a taxpayer's suit, brought to enforce the terms of the bond issue as it was approved at the polls.

\section{General Assessment Bonds}

The third category is general assessment bonds, which may or may not require voter approval. ${ }^{86}$ The bonds are the obligations of the issuing district, and are paid from a general fund ${ }^{87}$ All assessments and proceeds from sales of dehinquent property go into the fund. ${ }^{88}$

\section{Voter Approved General Assessment Bonds}

General assessment bonds which require voter approval ${ }^{80}$ should be treated the same as other types of voter approved bond issues. Landowners should liave no rights other than the riglit they have as taxpayers: the right to prevent legislative changes beyond the authority granted by the voters. In most cases, districts issuing general assessment bonds have broad statutory powers. ${ }^{90}$ The consent of the voters included these powers as they stood at the time of the favorable vote for the formation of the entity. The policy of public control of spending requires that clianges in the scope of these powers to the detriment of the taxpayer be prohibited.

In Sutter Basin Corp. v. Brown, ${ }^{01}$ the law existing at the time the bonds were voted was subsequently amended to allow the treasurer to

85189 Cal. 343, 208 Pac. 117 (1922).

88 See, e.g., CaI. Water Code $\S \S 52200-85$ (voter approval required); CaI. StrTs. \& Higers. CODE $\$ 8570$.

87 E.g., CaI. Strrs. \& Hitgrs. Code $\S 8671$.

88 E.g., CaL. STRrs. \& HigZs. CoDE. $\S \S 8800,8834$.

89 See, e.g., CAL. WATER CODE $\$ \S 52200-85$.

90 See, e.g., CaI. Water CODE $\$ \S 52200-28$.

9140 Cal. 2d 235, 253 P.2d 649, cert. denied, 346 U.S. 855 (1953). 
exclude certain monies from the bond fund. The court found a contract between the landowner and bondholder, and said that exclusion of funds would increase the burden on the landowner and impair his contract. Change in the statutes under which the voters measured their liabilities before approving the issue was correctly denied retroactive effect; the court sliould, however, have abandoned the contract theory as unreahistic in a voter approved situation and emphasized instead the grant of authority from the voters, and the conditions under which the authority was granted. The court sliould also have pointed out that the landowner was acting as a taxpayer, and that he had no special status as a landowner.

\section{Non Voter-Approved General Assessment Bonds}

When voter approval is not required for the issue of general assessment bonds, ${ }^{92}$ the bulk of authority in jurisdictions other than Califorma finds that legislative changes do not impair any contract of the property owner.$^{93}$ However, in California a contract of some sort is said to arise, and changes by the legislative body of the issuing entity or retroactive application of statutes passed after bonds have been issued may be resisted by the landowner if a court finds that they impair his contract. ${ }^{94}$

General assessment bonds issued without voter consent should not be treated as contracts. These general assessment bonds are secured by all the assessments in the district, ${ }^{95}$ not just a specific piece of property as are the direct lien bonds. ${ }^{96}$ The issuing entity has plenary control over the terms of assessments before bonds are issued. ${ }^{97}$ The issuance of bonds to represent the assessments sliould not alter this control so far as the assessee is concerned. The policy of direct public control of spending has no relevance to this type of bond. The issuing entity has control; within statutory limits, of the terms of both bonds and assessments before the bonds are issued. ${ }^{98}$ The issuing entity does not rehnquish its interest as

92 This type of bond may be illustrated by proceedings under the Improvement Bond Act of 1915, CaL. STRTS. \& Hitgers. CoDE $\$ \S 8500-851$. When improvements are proposed, landowners in an assessment district may be assessed in proportion to the value of the improvements to their property. $\S 8570$. The landowner is obligated to pay the assessment. $\S 4323$. However, if the governing body of the district decides that bonds should be issued, it may do so. $\S 8571$. The bonds, or the proceeds, are then used to pay the assessment. $\S 8623$. The landowners then pay the principal and imterest of the bonds periodically. $\S 8680$.

93 See Annot., 100 AL.R. 164 (1935).

94 See, e.g., County of San Diego v. Childs, 217 Cal. 109, 17 P.2d 734 (1932).

85 E.g., CaL. Stris. \& Higes. Code \& 8700.

${ }^{96}$ E.g., CAL. StrTs. \& Higrs. CoDE $\S 4573$. Bonds issued on general assessments represent a change from direct lien bonds, and were issued because they were more marketable. County of Los Angeles v. Rockhold, 3 Cal. 2d 192, 195, 44 P.2d 340, 341 (1935).

97 See Hershey v. Cole, 130 Cal. App. 683, 20 P.2d 972 (1933).

98 See, e.g., CaI. STRTS. \& Higes. CodE $\$ \S 8500-851$. 
it does with direct lien bonds. It maintains control over the collection of assessments for the benefit of all bondholders, ${ }^{90}$ and must protect the interests of these bondholders in order to maintain the market for its securities. Since no private relationship arises in connection with these types of bonds, this control should continue without the limitations imposed by a contractual analysis. If the statutory limits sufficiently control the entity before issue of bonds, they sliould be sufficient after issue. If greater control is needed, positive measures such as requiring voter approval slould be instituted.

\section{CONCLUSION}

In an analysis of the relationships between voter, bondholder, landowner, and bond issuing entity, it is important to distinguisl carefully the bases of the relationships, in order to understand the effect of legislative action on the parties.

Where assent of the electorate is necessary to incur bonded indebtedness, the relationship between the voter and issuing entity is much clearer if it is regarded not as a contract but as a grant of authority. The leading cases in California recognize that in order to carry out the policy of popular control of spending and indebtedness, detrimental financial changes or changes in purpose of a substantial nature in approved bond issues must be prevented. Analysis of the relationship between voter and issuing entity as a grant of authority from the voters effectively prevents changes beyond the terms of that authority. If provision for change is approved by the voters, it may be included in the terms of the bond issue. Permissible changes slould be clearly spelled out, lowever, and the provisions anticipating change should appear on the ballot.

In contrast, the relationship between a bondholder and the bond issuing entity is contractual. The contract includes the applicable statutes, the terms of the bond, and the terms of the authorization by the voters, if any. The constitutional provisions against impairment of the obligation of contract apply, and unless the bondholder consents, changes found to be impairment are prohibited.

The rights of the landowner should be treated as a contract only when a bond is a direct hen on his property. When he is liable for general assessments and no voter approval is required, the landowner should be treated as an ordinary taxpayer and so long as the issuing entity's authority remains within statutory limits the landowner should have no right to resist legislative action. If voter approval is required for the

99 E.g., CaI. Strts. \& Highs. Code $§ 8680$. 
issuance of bonds, the landowner should have only the rights of a taxpayer, and should not have any higher standing as a landowner which would enable him to prevent changes which were properly anticipated and provided for in the terms of the authorization.

Douglas R. Reynolds 